\title{
DE VITA REGULARI: LOS FRAILES AGUSTINOS EN EL ALCOY DEL XVIII (*)
}

\author{
José Luis SANTONJA CARDONA \\ Universidad de Alicante
}

"Ante todas las cosas, querídisimos hermanos, amemos a Dios y después al prójimo, porque éstos son los mandamientos principales que nos han sido dados"

(Regla de N. P. San Agustín) ${ }^{1}$

Los primeros agustinos que se instalaron tras la conquista de Valencia fueron los fundadores del convento de Aguas Vivas ${ }^{2}$. Por entonces se trataba de comunidades de eremitas que seguian la Regla de San Agustín (Africa, 388) pero no estaban reunidos en una Orden hasta que en 1256 el Papa Alejandro IV los agrupó en la de la de los llamados Ermitaños de San Agustín (O.E.S.A, Ordo Eremitarum Sancti Augustini) y en la que se integró la comunidad de Aguas Vivas. La llegada de los agustinos a Alcoy debió darse en el primer tercio del siglo XIV aunque el P. Jordán propuso una fecha anterior, en $1290^{3}$, mientras que el

(*) El presente artículo es en parte un extracto de los capítulos dedicados a los agustinos en mi tesis de licenciatura dirigida por el Dr. Mario Martínez Gomis Clero regular y protocolos notariales (Alcoy, 1700 1750): una visión sobre el mundo religioso de la época, Alicante, 1989, a la que me remito en el bagaje bibliográfico sobre el tema.

1 Agradezco gentilmente al P. Jesús Paniagua, OSA, el habeme prestado para su consulta la última edición traducida sobre la Regla agustiniana: Regla y constituciones de los hermanos de la Orden de San Agustín, Madrid, 1979, 278 págs. Para el análisis de los preceptos de la vida común se han utilizado las constituciones vigentes en el siglo XVIII y que fueron promulgadas en Roma en 1685. Un ejemplar de éstas se conserva en la Biblioteca General de la Universidad de Valencia, en latín, de fecha indeterminada (1686?), procedente de la libreria del Convento de San Agustín de Valencia (B.U.V., sign. Y- 68/83). Contiene: "Regula Sancti Augutini", pp. 27-42, "Expositio Ven. Servi Deo P. Alphonsi Orozco... super Regulam eiusdem S. P. Augustini”, pp. 43-133 y "Constitutiones Ordo Eremitarum Sancti Augustini”, pp. 134-517.

2 CARCEL ORTI, V.: Historia de la Iglesia en Valencia, vol. I, Valencia, 1986, p. 100.

FRANCH, R.: "El régimen señorial del Convento de Aguas Vivas durante el siglo XVIII" en Estudis, n" 8, Valencia, 1979-1980, pp. 223-271.

3 P. fr. Jayme JORDAN: Historia de la Provincia de los Reynos de la Corona de Aragón de la Sagrada Orden de los Ermitaños de Nuestro Gran Padre San Augustín, vol. II, Valencia, 1712, p. 112. 
P. Herrera afirmaba que la primera piedra del convento se colocó en $1300^{4}$. Un religioso posterior, el P. Picher sostenia, a media dos del XVIII, que la fundación ocurrió en $1338^{5}$, postura que es defendida por Ricard Bañó quien, sobre documentación localizada alusiva al monasterio, fija esta fecha como válida 6 .

El motivo de la introducción de los agustinos en Alcoy nos es desconocido salvando la hipotética alusión del P. Jordán (citando al mercedario Boil) a un deseo regio de Jaime I de promover la creación de un nuevo centro agustiniano

"en recompensa del Real Convento del Puiche (Puig de Santa Maria) porque haviendo sido el Convento del Puiche en su primera fundación de nuestra Religión (agustiniana) quando el Rey Don Jayme co(n)quistó Valencia, nuestros religiosos le pidieron la Virgen y sitio del Convento del Puiche y como el Rey lo avia dado a los Padres Mercedarios no pudo hazer la gracia a nuestra Religión y dexó encargado a su sobrina Doña Saurina de Entenza que en su villa de Alcoy edificasse un Convento de su real magnificencia al Glorioso Padre San Augustín en recompensa del de el Puiche"7.

El monasterio quedaba de esta forma bajo patronato de los señores de la villa (los Lauria) que lo dotarian con una renta anual de 200 libras sobre los ingresos de la bailia además del dominio directo de algunas tierras contiguas y casas de la población según la última voluntad de Margarita de Lauria ${ }^{8}$. Al volver la villa de Alcoy a manos de la Corona tras la muerte de su viudo, Nicolás de Janvila, la renta anual pasó a abonarse de los ingresos por razón de la peita real.

Ubicado en la parte alta de la población, el monasterio debió aprovechar una antigua fortificación levantada en 1265 durante las guerras fronterizas con Murcia, mientras la dirección de las obras se encargó a Berenguer Jofré, "lapicida et magister operis" de

4 P. Tomás de HERRERA: Alphabetum augustinianum in quo praeclara Eremitici Ordinis germina virorumq(ue) \& faeminarum domicilia recensetur, 2 vols., Madrid, 1644, donde nos dice: "Alcodiense [Monasterium] S. Augustini, Provinciae Aragoniae. Eius fundatrix fuit circa annum 1300 Domina Margarita de Lauria, uxor Nicolai Ianvillani, Comitis Terranovae, et filia Rogerii de Lauria et Saurinae de Entenza..." (vol. I, pp. 73-74) cit. item por DEL ESTAL, J. M.: "Prestigiosa biblioteca medieval escurialense de incunables procedentes del Convento de San Agustín de Alcoy" en Revista de Fiestas, Alcoy, 1978, p. 58. y BAÑO, R.: "El monasterio de San Agustín de Alcoi" en Ciudad Alcoy, 14 de enero de 1982

5 SANCHIS LLORENS, R.: Memoria sobre antigüedades históricas, Alcoy, 1986, p. 23.

6 BAÑO, R., art" cit.

7 P. fr. Jayme JORDAN, op. cit., vol. II, p. 112.

8 BAÑO, R., art" cit.

Id.: Alcoi durant el senyoriu de Frederic d'Aragó, comte de Luna (1409-1430), tesis de licenciatura inédita, Alicante, 1985, p. 188.

ONTALVILLA, L. de (seudónimo de Pascual Boronat y Barrachina) "El R. Convento de S. Agustín de Alcoy" en Revista Católica, n⿳ 514, Alcoy, 30 octubre 1897, p. 661.

VILAPLANA GISBERT, J.: Historia religiosa de Alcny, Alcoy, 1903, pp. 226-227.

Para una mayor profundidad en los aspectos fundacioralesdel convento vid. esp. SANTONJA CARDONA, J.L.: "El Real Convento de San Agustín de Alcoy: una aproximación histórica (siglos XIV-XIX)" en Anacleta Augustiniana (en prensa). 
Valencia. De la renta de 200 libras anuas sólo un tercio se entregaba a los religiosos y el resto quedaba depositado para los gastos de fábrica pese a las protestas de éstos que, considerando inapropiada su distribución, lograron por disposición regia disfrutar de la mitad de ellas en cada año?.

Desde su fundación el monasterio de San Agustín era el único centro conventual de la comarca hasta que a mediados del siglo XVI los franciscanos se instalaron en Cocentaina (1561) Ilegando a Alcoy en 1566 a instancias de las autoridades municipales y del pueblo en general que de este modo veia acrecentar su pasto espiritual. Año y medio después la población vivió los sucesos del escandaloso robo de las Sagradas Formas que se contenian en el sagrario de la Parroquia y cuya autoria se atribuyó a un desafortunado individuo, natural del Midi francés y residente en la villa que, víctima de las suspicacias de sus convecinos y tras una atípica investigación, fue condenado a muerte y ejecutado. En memoria de estos hechos el Consell local acordó edificar una capilla en el lugar donde se hallaron los objetos sagrados mientras el Patriarca Ribera propuso la erección de un convento de religiosas adosado al templete y dando paso para este fin a la creación de una nueva orden de agustinas reformadas ${ }^{10}$. De esta forma la comunidad agustiniana contempló la aparición de un nuevo centro conventual que junto al franciscano le representaba ya una competencia en las clientelas, legados y donaciones. Por otra parte el dominio directo que poseia sobre las tierras contiguas lo cedió a la villa en 1558 y 1565 para la construcción del "raval nou" a cambio de una compensación económica por via censal ${ }^{\mathrm{H}}$.

A fines del siglo XVI el convento entró en una gran actividad gracias a la figura de Doña Mencia de Avalos, viuda del caballero Don Pedro de Llanos, que originaria de Villena se instaló en Alcoy. Esta ferviente mujer se convirtió en la principal valedora de los agustinos a quienes encargaba su representación y la disposición de bienes. En 1591 propuso al convento la creación de un colegio anexo para la docencia de Artes y Teologia a estudiantes de la Orden y que se colocaria bajo la advocación de Santa Mónica ${ }^{12}$ mientras que el municipio, agradeciendo la cesión de parte del edificio conventual para el colegio, cedió a los religiosos algunas tierras cercanas por via de establecimiento en $1595^{13}$. Los agustinos, satisfechos por el interés de Doña Mencia, le permitieron construir su se-

9 ONTALVILLA, L. de, art ${ }^{\circ}$ cit., p. 661

10 CARBONELL, V: Célebre centuria que consagró la ilustre y r(ea)l villa de Alcoy a honor y culto del soberano Sacramento del Altar en el año de I668..., Valencia, 1672, pp. 36-87. 85.

SANCHIS LLORENS, R.: Alcoy y su monasterio del Santo Sepulcro (1568-1968), Alcoy, 1968, pp. 16-

VILAPLANA GISBERT, J., op. cit., pp. 279-293.

11 Escrituras del notario Joan Aiz del 26 de octubre de 1558 y 10 de mayo de 1565 , ambas inexistentes por la pérdida del fondo documental de este escribano. Las referencias las tenemos del P. Picher en SANCHIS LLORENS, R.: Memoria sobre antigüedades..., p. 24 y de L. de ONTALVILLA, art" cit., p. 660, aunque éste llama al notario Juan Alví y no Aiz.

12 VILAPLANA GISBERT, J., op. cit., pp. 306-307.

13 Escritura del 30 de marzo de 1595. Protocolo de 1594-1596 del notario Gaspar Cantó, s. f., Archivo Municipal de Alcoy (AMA). 
pultura en la capilla mayor de su iglesia y se obligaron a celebrar cuantiosas misas por su alma $^{14}$.

En este monasterio existian por otra parte dos cofradias asociadas, una la de Nuestra Señora del Consuelo, a la que se habia unido la de San Nicolás, y otra la del Dulcísimo Nombre de Jesús ${ }^{15}$. La primera, llamada también de la Correa del Gran Padre San Agustín, fue autorizada por Gregorio XIII en 1575 y confirmada en 1727 por Benedicto XIII aunque la de Alcoy no vió aprobados sus estatutos definitivamente hasta $1750^{16}$. Esta cofradia estaba presidida por un religioso agustino con el título de prior junto a mayorales y clavarios laicos. Su función casi exclusiva era la de fomentar el culto a su santa patrona y ayudar a los cofrades, especialmente en el momento de su muerte, dándoles sepultura en la fosa propia que tenia en la capilla de Nuestra Señora del Consuelo en la iglesia conventual. Aparte de las cofradias el monasterio acogió en 1684 a la Venerable Escuela del Santo Cristo, aunque por interrumpir los oficios de los religiosos se mudó a la iglesia de San Jorge hasta que en 1690 pudo adquirir la parte del convento que habia sido colegio de Santa Mónica, estableciendo una capilla dedicada a San Felipe Neri y permaneciendo allí hasta el desalojo de $1836^{17}$.

De este monasterio nos dice el P. Jordán a principios del XVIII que toda su fábrica es:

"de silleria, Iglesia, Claustro y Refitorio, no sólo las paredes sino también los techos de la Iglesia y Refitorio...la Iglesia tiene un Coro alto muy capaz adornado de una linda silleria que se compone de más de 60 sillas, tiene también una hermosa Sacristia con muy famosos ornamentos y un Trassagrario muy devoto y curioso. En los claustros ay muchas fuentes, enmedio de la luna un vivel con cinco caños y en medio de la cozina dos, todos de linda agua fres-

14 ONTALVILLA, L. de, art ${ }^{\circ}$ cit., p. 661

P. fr. Jayme JORDAN, op. cit., vol. II, pp. 113-114

El 10 de octubre de 1612 Doña Mencia dictó su testamento en el que dispuso el estado de la donación que habia hecho al colegio y convento: reconocia que entregó dos censales o juros que les respondian las villas de Alpera y Peñas de San Pedro por un capital total de 4. 000 libras, además habia gastado en la obra del colegio 16.000 reales castellanos y habia donado 900 libras al convento para que éste pudiese redimir dos censos a condición que mientras ella viviese le pasase su renta y avalase la parte que le tocaba en un censal de capital 5.000 libras que respondia al colegio de dominicos de Orihuela. Como condiciones finales establecia que se le diese una misa cantada diaria por su alma y la de su marido y que siempre tuviesen maestros capaces de en leer Artes y Teologia en él (Testamento, del 10 de octubre de 1612. Protocolo de 1612 del notario Miquel Valls, s. f., AMA). De todos modos este colegio no sobrevivió más allá de la primera mitad de siglo debido a la cortedad de su renta y a las trabas de la curia diocesana. SANTONJA CARDONA, J.L.: "La fundación de un centro de estudios de la Orden Agustiniana en el Reino de Valencia: el colegio de Santa Mónica de Alcoy", en Archivo Agustiniano (en prensa).

15 CARBONELL, V., op. cit., p. 157.

P. fr. Jayme JORDAN, op. cit., vol. II, p. 114.

16 VILAPLANA GISBERT, J., op. cit., p. 382.

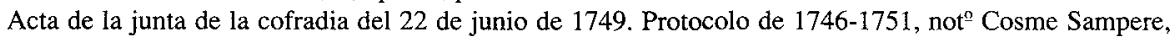
ff. 405-406, AMA.

17 P. fr. Jayme JORDAN, op. cit., vol. II, p. 114.

ONTALVILLA, L. de, $\operatorname{art}^{\circ}$ cit., p. 663. 
ca y cristalina. Es la luna del Claustro tan capaz que tiene muchos árboles plantados y se cria ortaliza y otras yerbas para recreo y regalo de los Religiosos. Los Dormitorios, libreria y demás pieças también son admirables de suerte que todos hazen un grande y célebre convento"18.

\section{LA CONSAGRACION A DIOS}

En el concilio de Trento se sentaron las bases de la regulación del acceso a probantes a los conventos obligando a las órdenes a adaptar sus constituciones a los nuevos preceptos. Los agustinos elaboraron las primeras normas comunitarias post-tridentinas en 1580 y posteriormente en 1685 (perdurando hasta 1800 y por tanto rigiendo la vida regular del XVIII). En estas constituciones se estableció que sólo podian entrar en los conventos jóvenes mayores de 14 años siempre que "sint bonae conscientiae, quieti, amatores virtutum ac perfectionis propensi ad devotionem" y se prohibia tomar "oblati" menores de 20 años y excepcionalmente con licencia del superior general o provincial. Se excluia como probantes a los sospechosos de apostasia, herejia, descendientes de reos de inquisición, siervos o casados ("qui fuerit de Apostasia a Fide vel de Haeresi...neque sit natus ex Par(en)tibus et Avis per sanctum Inquisitionis Officium de Apostasia a Fide vel de Haeresi...punitis et damnatis neque servuus neque matrimonio consummato ligatus"), perseguidos por deudas, enfermos contagiosos, hijos ilegitimos o frailes de otras órdenes mendicantes ${ }^{19}$.

El pretendiente debia sortear además otra traba: dos religiosos lo examinaban e informaban de sus capacidades al prior. Si pasaba la prueba podia abandonar la ropa del siglo y tomar el hábito ante el resto de la comunidad con los símbolos de la Orden: escapulario, capa negra y correa. Otorgaba una profesión de votos simples y empezaba la probación que duraria como mínimo un año y un dia ${ }^{20}$.

Tras el ingreso en el noviciado, el provincial de la Orden podia destinarle a cualquier otro convento que se considerase más capacitado para su instrucción ${ }^{21}$. Los novicios quedaban bajo la dirección de un maestro que casi siempre resultaba ser un titulado en gramática latina pues es en esta etapa cuando más se va a profundizar en el estudio del latin al nivel que permita al futuro fraile la correcta comprensión de los textos sagrados o de las obras de los clásicos, mientras al mismo tiempo se les introducia progresivamente en los preceptos de la Regla.

Transcurrido el plazo prudente de la probación y si el novicio era mayor de 16 años, se presentaba a examen para calificar sus capacidades mientras se requeria el consenso de la comunidad para su ingreso. Si superaba ésto se le hacia una referencia sobre los votos y preceptos regulares de su futura vida de fraile y se preparaba la profesión. El progenitor

18 P. fr. Jayme JORDAN, op. cit., vol. II, p. 112.

19 (Regula et constitutiones Ordo Eremitarum Sancti Augustini) Pars secunda...In qua tractatur de Observantiis nostrae sacrae Religionis. Cap. I. De aetate \& qualitate eorum qui ad Ordinem recipiendi sunt, pp. 39-44.

20 Ibid, Cap. II. De receptione Novitiorum, pp. 45-52.

$21 \mathrm{Ibid}$, Cap. III. De educatione Novitiorum \& qualis esse debeat Magister eorum, pp. 53-63. 
del novicio o incluso la propia comunidad de religiosos instruia un certificado de limpieza de sangre por el que unos testigos de reconocido prestigio, generalmente miembros de la élite local, aseguraban ante escribano público que los ascendientes del pretendiente de hábito "fueron buenos Christianos antiguos sin rasa ni mácula de Moros, Judios ni de otra mala secta ni de los nuevamente convertidos a Nuestra Santa Fe Católica ni an sido penitenciados ni castigados por el Santo oficio de la Inquisición ni por otro Tribunal..."22. Se evitaba de esta forma el acceso al convento de individuos con antecedentes familiares de conversos o reos de inquisición o de cualquier otro tribunal puesto que no se admitia que con faltas pendientes pudiese en el futuro acogerse a la inmunidad eclesiástica frente a los tribunales civiles. Tras probar su origen familiar el novicio debia deshacerse de los bienes que poseia pues era mandato de la Regla que " los que tenian algo en el siglo cuando entraron en la casa religiosa, pongánlo de buen grado a disposición de la comunidad"23. El medio para esta renuncia a bienes materiales era el testamento civil o en ocasiones cualquier otro tipo de escrituras de cesión. Pero esta interdicción a la posesión de bienes mundanos tenia la excepción de que el profeso pudiese reservar su usufructo mediante el arrendamiento o la obligación de sus familiares a pasarle una renta por los derechos de herencia a los que renunciaba. El testamento por otra parte tenia la función de dar fe de la muerte del profeso para el siglo y en ocasiones disponia lo que debia hacerse a su óbito; en todos los casos los novicios al testar renunciaban a cualquier derecho de herencia que hubiesen, morian para el mundo y fijaban que cuando falleciesen fuesen enterrados con el hábito que llevasen en la sepultura propia de la comunidad donde residiesen y se instituyera un aniversario en su memoria. Todos estos testamentos se caracterizaban por su brevedad puesto que la mayoria no incluia cláusulas decisorias y no abarcaba más de folio y medio en los protocolos notariales, lo que en relación a la extensión característica de otros testamentos es muy significativa del nivel formulativo con que se redactaban ${ }^{24}$.

La profesión de votos implicaba el fin del noviciado y la entrada en la vida regular, apareciendo como una sencilla celebración en la que el nuevo fraile era acogido entrañablemente por el resto de religiosos. Un ejemplo de este cálido recibimiento lo tenemos en la descripción que un notario alcoyano nos dió de fray Fulgencio Pericás pues éste "tomando el Libro de las Profesiones en sus manos leyó al pie de la letra su profesión y dándose p(o)r muerto civil(ment)e al siglo, ofrezió vivir y morir santam(ent)e en dicha Santa Religión y succesivam(ent)e entonó dicha Santa comunidad e(n) assimiento de Gracias el Himno Te Deum Laudamus, concluido con preces, antífonas y oración, abrasó el dicho fray fulgencio a todos los de dicha Comu(nida)d en señal de su her(manda)d"25. En el acto de profesión el nuevo fraile prometia cumplir los tres votos de la Regla agustiniana: casti-

22 Escritura del 14 de marzo de 1714. Protocolo de 1714-1717 del notario Pedro Tarassona, ff. 36-37, AMA.

23 Regla y constituciones..., p. 7.

24 Las propias constituciones requerian la presencia obligatoria del notario para dar fe de la profesión y garantizar la libertad del probante a hacerla tal como se estipuló en Trento. (Regula et constitutiones) Pars secunda...Cap. IV. De modo \& forma Professionis faciendae, pp. 64-75.

25 Escritura del 19 de diciembre de 1750. Protocolo de 1750-1751 del notario Tomás Gisbert, ff. 73-74, AMA. 
dad, pobreza evangélica y obediencia. El valor de la primera se entendia no tanto en continencia en cuanto tal sino en su consagración a Dios pues capacitaba para un mayor amor al Padre y disponia las voluntades a la dedicación exclusiva al servicio de Cristo y de la Iglesia ${ }^{26}$. El segundo voto presuponia la comunidad total de bienes, el no tener nada en propiedad pero sí reservativamente en usufructo mientras la promesa de obediencia se ampliaba tanto al servicio de Dios como de los superiores de la Orden en bien de la comunidad fraterna. Una vez realizada la profesión se le entregaba el hábito negro propio de los agustinos y quedaba admitido en la vida de hermandad de los frailes.

Al contrario que en los conventos femeninos, en los masculinos como éste de San Agustín no se exigia ninguna cantidad por razón de ingreso pero se instaba a que se asegurase una renta anual y vitalicia para los gastos propios que pudiese tener. En los años de probación, sus familiares corrian con los gastos de alimentos cifrados en unas 24 o 25 libras mientras debian proporcionar antes de su profesión diversas ropas a éste y a la comunidad tales como dos o tres hábitos, ropa interior, zapatos, ropa de cama, sombreros y mobiliario de uso personal ${ }^{27}$.

La mayoría de los novicios eran naturales de la misma villa y en ocasiones de poblaciones más o menos cercanas como Cocentaina, Muro, Olleria o Bocairent, aunque algunos podian provenir incluso de otras provincias de la Orden. En cuanto a su extracción social procedian de familias de la élite local como ciudadanos o profesionales liberales y en menor medida de artesanos o labradores. En el primer caso se trataba de segundones que con escasas posibilidades de promoción social buscaban un camino alternativo en la religión mientras que en el segundo caso sí se consideraba un verdadero ascenso.

\section{Tabla 1. Novicios profesos del Convento (1700-1800)}

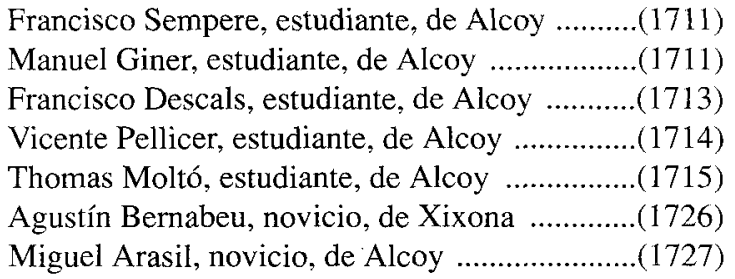

26 Regla y constituciones. ., p. 64.

27 EI cirujano Juan Almiñana gastó antes de la profesión de su hijo fray Joseph unas 98 libras distribuidas del siguiente modo: 24 libras de alimentos del año de noviciado, cuatro libras y media por un hábito blanco usado, diez libras y media por uno negro, ocho libras por otro blanco nuevo, tres libras y media por dos sábanas para el convento, cinco libras y media por otras dos, cuatro libras por cuatro camisas y cuatro calzones, dos libras y media por tres jubones, una libra por dos pares de calzones, media libra por un sombrero, dos libras por una cama de pino, dos libras y media por una manta y media por dos fundas de almohada, media más por tres servilletas, dos libras y media por un arca, una libra por una mesa, cinco libras por dos breviarios, otras cinco por dos colchones y doce libras por dos veces que tuvo conclusiones.

Testamento de Juan Almiñana, del 4 de febrero de 1738.

Protocolo de 1737-1738 del notario Pedro Barber, ff. 24v-27, AMA. 
Francisco Reig, novicio, de Muro

Vicente A. Sanchis, novicio, de Enguera

Joseph Bou, novicio, de Benimantell

Isidro Soler, estudiante, de Alcoy

Fulgencio Pericas, novicio, de Alcoy

Antonio T. Fort, novicio, de Cartagena

Joseph Mollà, novicio, de Olleria

Francisco Sanchiz, novicio, de Callosa

Juan Bta. LLob, novicio, de Ruzafa

Gaspar Escrivá, novicio, de Font d'en Carrós ...(1764)

Joseph Assencio, novicio, de Bocairent

Miguel Miralles, novicio, de Alcoy

Thomas Almiñana, novicio, de Alcoy

Vicente Moltó, estudiante, de Alcoy

Isidro Mataix, novicio, de Alcoy

Francisco T. Catalá, novicio, de Carcaixent..... (1779)

Joseph Gosalbez, novicio, de Alcoy

Pedro Ivorra, novicio, de Benidorm

Joaquin T. Vicent, novicio, de Ayelo

Vicente C. Buigues, novicio, de Teulada

Francisco Ferrando, novicio, de Callosa

\section{LA VIDA DE ORACION}

Los orígenes eremíticos de la Orden agustiniana implicaban la perseverancia de la oración comunitaria ininterrumpida y con su máxima expresión en la celebración de las horas litúrgicas. Estas se agrupaban en matutinas y nocturnas y dependian de la estación en que se encontrasen pues se celebraban en relación con las salidas y ocasos del sol. De esta forma el nuevo dia empezaba con los primeros rayos del alba cuando se acudia al oficio de laudes, inicio de la jornada, siendo quizás la celebración más importante del dia, a la que seguia el frugal desayuno tras el que se iniciaban las actividades cotidianas de los frailes. Poco tiempo después tocaban los oficios de prima, cerca de las siete de la mañana, teicia, sobre las nueve, y sexta a mediodia, dando paso a la comida. La tarde se completaba con la nona, a las tres, y vísperas, al ocaso, mientras de noche se celebraban las completas. Como hora nocturna se acudia a maitines o vigilia entre las dos y las tres de la madrugada. De todas estas celebraciones las más importantes son las de laudes, como apertura del nuevo dia, y vísperas, porque suponia el cese de cualquier otra actividad hasta la jornada siguiente.

Aparte de las horas canónicas existian otros oficios instituidos por la Orden y que estaban regulados en las constituciones. Podian tener carácter diario (la "missa conventualis") o temporal en fecha fija o móvil coincidiendo con determinadas festividades o con celebraciones de difuntos. De forma general en todo el universo agustiniano se celebraban las fiestas a determinados santos: en el caso de la Virgen de Gracia (de especial culto entre ellos) se rendia un prolongado ofico litúrgico "cum tribus psalmis, tribus lectionibus \& duobus responsoriis" mientras a su término debia entonarse devotamente "genibus flexis 
Antiphona Ave Regina Caelorum Mater Regis Angelorum étc..."28. El Convento de Alcoy habia instituido por su parte una celebrada fiesta en honor de Santo Tomás de Villanueva en la que, aparte de los consabidos oficios, se habia acostumbrado ofrecer una comida gratuita para los pobres vergonzantes que allí acudiesen en el cuarto domingo de septiembre de cada año 29 .

Los oficios de difuntos se estructuraban en tres ámbitos, según a quienes se recordaba, es decir, a benefactores o cofrades, a los propios hermanos y a los superiores de la Orden o al Papa. Por los primeros se celebraba misa obligatoria en el segundo domingo de cada mes; en el caso de los frailes difuntos se solia celebrar en su aniversario ya que era costumbre que con sus rentas instituyesen oficios particulares en su memoria, mientras se ordenaba que después de la festividad de San Miguel se hiciese una misa "pro Fratribus \& Familiaribus Propinquis \& Benefactoribus Ordinis Nostri defunctis omni anno", o sea, integrando en el recuerdo de la oración a religiosos, familiares y protectores suyos. Por último las constituciones regulaban los oficios en caso de fallecimiento de superiores eclesiásticos como el papa, su sacristán (que siempre era agustino), el cardenal de la Orden, el procurador o el asistente general, y se realizaban diez dias después de su óbito, cuando supuestamente ya se debia conocer, oficiando "vigiliae cum Laudibus \& Missa Defunctorum solemniter" 30 .

Dentro de los oficios el canto constituia un elemento esencial. Los conventos con más de veinte frailes como el de Alcoy debian cantar diariamente en la misa conventual y en las vísperas, mientras se establecia que todo coro debia contener como mínimo:

"unum bonum Missale...et duo bona Antiphonaria...unum diurnum et aliud nocturnum et Hymnarium...et ad minus unum bonum Psalterium et unum Manuale...item Breviarium in quo legantur nocte lectiones debitae..." 3 ?.

mientras se exhortaba a entonar grave y acertadamente los ejercicios $\operatorname{corales}^{32}$, al tiempo que se prohibia cualquier música "indecente".

La asistencia a estos oficios era obligatoria para todos los hermanos con las excepciones de aquellos cuya labor era la base del ideal agustiniano: los maestros de Teologia y Filosofia y los predicadores, pues su extrema dedicación no les permitia compatibilizar todas las celebraciones. Las faltas de asistencia o los retrasos al coro eran penados por medio de la humillación ante el resto de la comunidad pues para expiar su culpa el religioso "comedat in terra in medio Refectorii" o se postraba ante el prior reconociendo su falta mientras que en caso de reincidir este tipo de prácticas se agravaba hasta obligar al fraile a

28 (Regula et constitutiones) Primar pas. De divino culto \& de his quae ad eum spectant. Cap. I. De officio divino a Fratribus \& Monialibus nostri Sacri Ordinis per soluendo et de oratione serotina, pp. 7-12.

29 VILAPLANA GISBERT, ., op. cit., p. 350.

30 (Regula et constitutiones) Prima pars...Cap. II. De missa \& processione defunctorum..., pp. 12-16

31 Ibid, De libris habendis ad usum Chori, pp. 25-26.

32 Se estableció un "modus cantandi" en que "omnia que cantanda fuerit mediocri \& gravi tono cantentur cum debitis pausis \& accentus...". (Regula et constitutiones) Prima pars... Cap. III. Quando Missa Conventualis \& Officium in Choro debeat chantari \& de his qui canonicis horis per soluendiis \& Missae Conventuali interesse debeant, pp. 16-20. 
estar "inclinado sobre el suelo y golpeándose el pecho [repetidas veces] para reconocer su culpa"33.

Al margen de los oficios intrínsecos a la vida conventual, el obligado pasto espiritual de los laicos se tornaba en varias medidas: aceptándolos en las celebraciones propias del convento, las misas de carácter votivo en fiestas, las misas obligadas de domingo o las misas y oficios instituidos por seglares tanto vivos como muertos. Estas fundaciones podian ser obras pias de culto (dotación de lámparas, novenas a santos, jubileos o fiestas), de beneficencia (escuelas, dotes para maridar huérfanas, comidas para pobres) o de misas, que eran las típicas instituciones. Su administración la llevaba la comunidad por medio del obituario, una lista de difuntos establecida sobre un calendario para recordar los servicios funerarios fundados y que debian darse. En esta época se instituyen obras pias de culto en el Convento de San Agustín como dotación de horas canónicas, lámparas de altares o fiestas de santos como San José o Nuestra Señora de la Correa, donde se incluia una comida para los frailes. Las misas de fundación suponian la mayor parte de las obras pias que se creaban y podian ser rezadas o cantadas, mucho más caras y conocidas como "doblas". El dia de su celebración variaba pues algunas eran de aniversario, otras en la fiesta de un santo, en fechas fijas o móviles o incluso diarias. Las primeras se celebraban por primera vez un año después del fallecimiento del instituyente y en el dia de su óbito, mientras que el resto se fundaba en fiestas de santos (Virgen del Consuelo, San José, San Francisco Javier, San Antonio de Padua, étc. ), familias (Sempere) o de difuntos (dos de noviembre). Frente al resto de conventos de la villa el de San Agustín es el que mayor número de instituciones recibia, casi a un nivel monopolizador, y también las de mayor cuantia.

Aparte de las fundaciones la simple celebración de misas inmediatas por los difuntos que las encargaban al Convento en sus testamentos significaba aun un mayor incremento de los oficios que se debian cumplir, contribuyendo todo ello a que la conjunción de mandas de misas de laicos, de clérigos o de los propios religiosos y de las conventuales ocupasen casi todo el espacio diario y que con el tiempo se tuviese que aplicar mayor número de oficiantes a ello. Además la estructura de la propia comunidad estaba en función del papel que cada uno debia ejercer en la liturgia distinguiéndose así entre sacerdotes, coristas y hermanos de la obediencia que actuaban como ayudas de celebración, pues la propia Regla establecia que "en el oratorio nadie haga sino aquello para lo que ha sido destinado, de donde le viene el nombre" 34 .

\section{LA VIDA EN COMUNIDAD}

Todos los objetivos y fines de la Orden Agustiniana se basaban en la perfecta armonia de la vida en comunidad de los frailes para lo cual toda la actividad de los religiosos debia enmarcarse dentro de las necesidades del común de hermanos y por ello la observancia es-

33 Ibid., Cap. IV. De his qui Missae vel Horis Canonicis no intersunt vel tarde ad huismodi Missam vel Horas veniunt aut in Choro cantando vel legendo deficiunt, pp. 20-22. Este medio de expiación por prácticas humillatorias era el más seguido en los casos de desobediencia, dejadez o cualquier falta a la Regla sancionada por el superior. En otras ocasiones, como veremos más adelante, el castigo llegará a ser físico.

34 Regla y constituciones..., p. 9. 
tablecia que los bienes no fuesen a título particular sino de hermandad, que la oración fuese igualmente compartida y que incluso en el exterior los frailes procuraran viajar juntos. Esta vida común afloraba en casi todos los puntos de la Regla pues aparecia como fin ("vivid en las casas unánimes y tened una sola alma y un solo corazón orientados hacia Dios"), como medio de subsistencia ("no poseáis nada propio sino que todo lo tengáis en común") o de mostrarse al mundo ("cuando salgáis de casa, id juntos; cuando lleguéis a donde os dirigís, permaneced juntos") 35 . La misma comunión se ofrecia en las actividades cotidianas: en la comida era obligado que todos asistiesen en silencio y mientras comieran escuchasen lo que se leia absteniéndose de conversar sin razón o de murmurar; en el tiempo de recreo los hermanos podian dialogar o recibir visitas con licencia del superior. En el caso de religiosos de otras casas, el espíritu de la Orden les daba derecho a una hospitalidad verdaderamente fraterna siempre que se sujetasen a la disciplina del convento y a la autoridad del prior.

En el caso alcoyano esta comunidad regulada vendria reforzada por la existencia de unos lazos de parentesco entre muchos religiosos puesto que al proceder gran parte de ellos de la propia villa solian guardar relaciones familiares entre sí, encontrando hermanos como los Padres fray Francisco y fray Máximo Descals, los Padres fray Nicolás y fray Thomás Moltó y los Padres fray Agustín y fray Francisco Tudela o emparentados como los Padres fray Aurelio y fray Christoval Aiz y los Padres fray Basilio y fray Joseph Gisbert, mientras que habia casos de religiosos como el Padre fray Juan Lagier y fray Christoval Terol, de la Obediencia, que se asociaron en distintos negocios.

La vida en comunidad se basaba en el respeto mutuo entre todos los hermanos; la Regla prohibia cualquier disputa entre sus miembros ("no haya disputas entre vosotros o de haberlas terminadlas cuanto antes para que el enojo no se convierta en odio y de una paja se haga una viga, convirtiéndose el alma en homicida") y exaltaba a pedir a pedir perdón prontamente al ofendido ("cualquiera que ofenda a otro con injuria, ultraje o echándole en cara alguna falta, procure remediar cuanto antes el mal que ocasionó y el ofendido perdónele sin vacilación") aunque con la excepción que los maestros o los superiores no tuviesen obligación de pedirlo a los menores puesto que "no sea que por guardar una excesiva humildad para con quienes deben estaros obedientes se debilite del que gobierna" 36 . Respeto y obediencia debia guardarse al superior de la casa "como a un padre" pues éste aparecia como representante de la divinidad y debia velar por la observancia de los preceptos de la Regla.

Los pilares básicos para la perfecta ordenación de la vida comunitaria se sentaron en el control de la actividad de los hermanos en todas sus facetas: mentalmente mediante los confesores y corporalmente mediante la distribución del trabajo. Las constituciones reforzaban la potestad de los priores conventuales ya que debian ser los únicos confesores para la comunidad aunque se admitia que, debido a sus excesivas ocupaciones delegasen en otro religioso. Los novicios, por su parte, disponian de confesores particulares pero que nunca debian ser sus maestros. Así por este medio, el superior controlaba a los hermanos

35 Ibid, pp. 7 y 13.

36 Ibid, pp. 19-20. 
en un intento de mantener la integra observancia de la Regla e incluso el confesor estaba limitado en sus funciones pues requeria del prior licencia para absolver faltas que eran consideradas graves en persona religiosa como el hurto, el pecado carnal, la conspiración, la simonia, la violencia contra personas, la piromania, la nocturnidad y la apostasia. En estos casos, el confesor debia comunicar la falta al superior y éste obraria en consecuencia, sacrificándose de este modo el secreto de confesión en beneficio del control de los preceptos regulares ${ }^{37}$.

En cuanto al trabajo, las constituciones de los agustinos consagraban la vida laboral extendida a todos sus miembros. En los manuales de observancia de la Regla se indicaba que todos los religiosos debian trabajar incluidos los sacerdotes en sus ratos libres y no "creyéndose con derecho para estar después [de asistir a los oficios litúrgicos] holgando, para desperdiciar las horas que restan en conversaciones y visitas inútiles y tal vez peligrosas, para buscar pasatiempos, jugar a naypes, ..."38. actividades lúdicas que por otra parte estaban anatemizadas por la Orden. El trabajo se distribuia en función de la dedicación de los hermanos: los legos o profesos de servicio se dedicaban a labores manuales mientras que el resto se ocupaba del gobierno (prelados superiores y locales), el estudio (maestros y estudiantes) o la asistencia espiritual (confesores y predicadores). Ocasionalmente podian aducirse otras causas para no trabajar como "la debilidad o enfermedad del cuerpo" o más curiosamente en aquellos que tenian "delicadeza natural de complexión", es decir, hermanos que nunca habian ejercido profesión manual y posiblemente debian proceder de los estamentos privilegiados ${ }^{39}$. Los legos, sobre quienes recaian las labores de servicio del convento, acabados los oficios ordinarios, se dedicaban a:

"hacer escobas, pleyta para esteras o espuertas y otras obras de esparto, instrumentos de penitencia como silicios y disciplinas, reloxes de arena y dispertadores de agua, cestas, canastillos y demás cosas útiles que pertenecen al artificio de cañas y de mimbres, pueden trabajar de cordoneria o hacer jaulas de alambre o de juncos para guardar las avecillas, pueden también coser hábitos y otra ropa de la Comunidad o de la Iglesia, plantar, criar e ingerir árboles y cultivar la huerta del Convento"40.

37 (Regula et constitutiones) Prima pars... Cap. VIII. A quibus secretae Confessiones Fratrum Ordinis audiantur \& de Casibus reservatis, pp. 30-37. Desarrolla estas faltas con los términos de "furtum de re notabili sive res communis sit sive alicuis usui deputata", "lapsus carnis voluntarius opere consumatus", "coniuratio omnis \& conspiratio", "simonia tam in dante quam in accipiente", "occisio aut vulneratio seu gravis percussio cuiuscumque personae animo deliberato facto", "incendium ex malitia factum vel procuratum", "sine licentia extra loci septa de nocte exire" y "apostasia comittere vel alicui persuadere".

38 P. fr. Basilio Tomás ROSELL: El monacato o tardes monásticas en que hablándose en general de las obligaciones y costumbres de los Monges se desciende en particular a las de los Agustinianos, Valencia, 1787, p. 145. Este libro puede presentarse perfectamente como un manual dirigido a los novicios para instruirles en la historia y la observancia de la Regla agustiniana, desarrollándose mediante la fórmula clásica del diálogo entre dos religiosos sobre las excelencias de su Orden.

39 lbid., pp. 152-153.

40 Ibid., p. 158. 
Las constituciones asimismo establecian que ningún religioso podia introducir ropas del exterior pues para su uso debia proporcionarlas el prior generalmente por San Miguel. Como tejidos quedaban prohibidos el lino para la ropa interior y el paño al exterior, para evitar su ostentosidad ("qui nimis est carus secundum consuetudinem Patriae \& nostrae quotidianae mendicitati non respondet") mientras debia vestirse siempre con un escapulario corto con capucha blanca, capa con las mangas largas y correa de cuero negro de dos dedos de anchura y con medias calzas blancas anudadas a la pierna. En toda manera se prohibia llevar ropa de otro color que no fuese blanca al interior y negra al exterior so pena de suspensión "a divinis", llevar pieles salvo prescripción médica o calzado que no fuese de cuero negro, y se obligaba a usar la capa siempre que se saliese al exterior. El incumplimiento de cualquiera de estos preceptos se castigaba primero haciendo que el religioso comiese en el suelo durante tres dias y en caso de reincidencia aplicándole la disciplina ${ }^{41}$.

El convento por otra parte entregaba a cada fraile una celda particular pero con llave común con la obligación de que éste mantuviese las paredes exentas y como único mobiliario un camastro, una mesa y una linterna para el estudio nocturno ${ }^{42}$. Para la comida se obligaba a que todos los religiosos acudiesen al refectorio donde, después de lavarse las manos, se sentaran en silencio y cada uno en su lugar. Tras la bendición y el signo del prior podian empezar a comer mientras se leian por los miembros más jóvenes (novicios, profesos recientes o frailes de menor edad) escenas de la Biblia, los Evangelios, sermones de San Agustín o crónicas de la Orden ${ }^{43}$. El ayuno se guardaba cuando estaba instituido y su falta se penaba indefectiblemente con la postración en el suelo y a comer pan y agua ${ }^{44}$.

Otros aspectos de la vida comunitaria como la asistencia a los hermanos enfermos o el hospedaje también se regulaban en las constituciones. En caso de enfermedad de algún fraile el resto de religiosos debian acudir pronto, disponiéndose de entre ellos uno para auxiliar al enfermo sin renunciar a la ayuda médica aún por persona ajena a la casa, dejando así acceso libre a los médicos de la población ${ }^{45}$. En cuanto a la recepción de huéspedes, los conventos podian aceptar a cualquier persona "de buenas costumbres" siempre que el hospicio quedase separado del dormitorio de los frailes y que en todo caso los huéspedes permaneciesen sujetos a la autoridad del prior y a las costumbres de la casa. Los individuos del estado eclesiástico podian acceder con licencia del superior "intra claustra" 46 .

El gobierno del convento se decidia exclusivamente en los capítulos provinciales que se celebraban regularmente cada tres o cuatro años, periodo que se correspondia con la duración de los cargos de la comunidad que allí se elegian, a saber: prior, subprior, confesor de

41 (Regula et constitutiones) Pars secunda...Cap. V. De forma \& qualitate vestium Fratrum \& quando debeant Cappam iuxta temporum varietatem deferre, pp. 76-84, y Cap. VI. Quomodo \& quando Fratribus devestibus debeat provideri, pp. 84-87.

42 Ibid, Cap. VII. De Cellis Fratrum \& earum supellectili ingressu ac visitatione, pp. 87-89.

43 Ibid., Cap. IX. Qualiter ad refectionem intrent \& sedeant Fratres, pp. 91-99.

44 Ibid., Cap. X. De uso ciborum \& ievinio Fratrum, pp. 99-103.

45 Ibid., Cap. XIV. Quante \& qualis cura \& sollicitudo haberi debeat circo infirmos, pp. 115-121.

46 Ibid, Cap. XVI. De humanitate hospitibus exhibenda \& ad quid hospites nostri Ordinis teneantur, pp. 128-134. 
monjas, maestro de novicios, sacristán, procurador y depositarios de la comunidad ${ }^{47}$. El prior era designado de forma colegiada por el presidente del capítulo, el provincial, definidores y otros tres padres de reconocido prestigio, entre aquellos religiosos de edad madura, celosos del orden y eruditos en sagradas letras. En el convento el prior, que podia proceder de otras casas, regulaba la vida de la comunidad tanto como superior que como padre, con el auxilio del subprior y de los consejeros que solian ocupar las cátedras de Teologia y Filosofia.

\section{Tabla 2. Priores del Convento (1700-1750)}

$\begin{array}{llll}1699-1702 & \text { P. fr. Visent Garcia } & 1726-1729 & \text { P. fr. Antonino Sanchis } \\ 1702-1705 & \text { P. fr. Thomas Carbonell } & 1729-1732 & \text { P. fr. Francisco Alonso } \\ 1705-1708 & \text { [Desconocido] } & 1732-1735 & \text { P. fr. Guillermo Gisbert } \\ 1708-1711 & \text { P. fr. Thomas Serrano * } & 1735-1738 & \text { P. fr. Francisco Alonso } \\ 1711-1714 & \text { P. fr. Thomas Almenar * } & 1738-1741 & \text { P. fr. Gabriel Miralles } \\ 1714-1717 & \text { P. fr. Próspero Gisbert } & 1741-1744 & \text { P. fr. Gabriel Miralles } \\ 1717-1720 & \text { P. fr. Antonio Gisbert } & 1744-1747 & \text { [Desconocido] } \\ 1720-1723 & \text { P. fr. Andrés Abat } & 1747-1750 & \text { P. fr. Vicente de Fanlo* } \\ 1723-1726 & \text { P. fr. Antonino Sanchis } & 1750-1753 & \text { P. fr. Gerónimo Gisbert }\end{array}$

* Priores procedentes de otros conventos

El subprior era el segundo en la jerarquia de la casa, sustituyendo al prior en su ausencia o con licencia del provincial en caso de muerte o incapacidad. Aparte de ello debia controlar los útiles y materiales que se guardaban en el convento y mantener siempre informado al prior sobre los asuntos de orden de la comunidad ${ }^{48}$. El sacristán por su parte estaba encargado del cuidado del templo y de los objetos litúrgicos, de las reliquias, de atender las campanas y horas y de llevar escrupulosa cuenta del libro de limosnas y cómputo de misas instituidas ${ }^{49}$. Para los negocios del siglo se disponia de un procurador religioso y en ocasiones de seculares, mientras los dos depositarios se ocupaban de llevar las cuentas de la casa, guardar las llaves del depósito (una de las cuales tenia el prior) y del archivo, realizar inventarios de bienes y llevar los libros de entradas (introitus) y salidas (exitus) ${ }^{50}$.Por último, el bibliotecario quedaba atendido a

"cuidar de la limpieza, conservación y aumento [de la biblioteca], a arreglar en los caxones las clases de libros por Facultades y a formar Indices para el cómodo uso de los que haya"51.

47 Ibid., Tertia pars. De Universi Ordinis Gubernatione. Cap. X. De Agendis in diffinitorio Capituli provincialis...De institutione Priorum, Suppriorum, Confessorum Monialium, Magistrorum Novitiorum, Sacristarum, Procuratorum \& c., pp. 251-257.

48 Ibid, Cap. XIX. De Officio \& aucthoritate Supprioris, pp. 347-351.

49 Ibid., Cap. XX. De Officio Sacristae Conventus, pp. 351-358.

50 Ibid, Cap. XXI. De Officio Procuratoris..., pp. 358-363, y Cap. XXII. De Officio Depositarum. ., pp. 363-368.

51 P. fr. Basilio Tomás ROSELL, op. cit., p. 160. 
Todo este conjunto de regulaciones y preceptos de la vida comunitaria se elaboraba en función de dos objetivos que se nos antojan esenciales, por una parte la salvaguarda de la clausura tras los muros del convento y por otra de la castidad, mediante el continuo control de los hermanos por los superiores. Ante la presencia femenina el fraile debia aplicar las interdicciones que habia aprendido: la mujer no podia acceder al coro ni ingresar en el claustro bajo pena de supensión "a divinis" del que lo permitia, mientras que si quisiese hablar con ella debia estar presente otro fraile. En la confesión se podia oir libremente a las mujeres en el templo pero si se salia al exterior el religioso debia procurarse necesariamente la licencia del superior.

Además la castidad cobró una especial relevancia ya que para muchos religiosos se convirtió en el fin último del espíritu regular pues como se decia:

"adónde se encaminan los ayunos, la perenne meditación de las cosas del cielo y las horas continuas de oración sino a conservar entera la castidad",

opinión que enmarcaba una excesiva acotación de tipo sexual a las relaciones con el mundo puesto que así se reducian todas las tentaciones del siglo a una sola y aún más indicando que "nuestra Regla no prohibe ver las mugeres sino apetecerlas o querer que ellas nos apetezcan"s2.

\section{LA DEDICACION AL ESTUDIO}

Consagrados a la misión salvífica de la Iglesia y para robustecer continuamente el fundamento de la vida espiritual de la Orden, los agustinos debian dedicarse "con el mayor interés al estudio de todas las artes y disciplinas humanas y divinas, en bien de la Iglesia, de la Orden y de la sociedad humana"53, especialmente a los estudios eclesiásticos y la historia agustiniana. Con este proyecto el monasterio se convertia en un centro docente con un cuadro de religiosos apropiado para este fin, compuesto por lectores y maestros. Cada uno de ellos contaba con un aula donde impartia una determinada enseñanza conocida como "studium" sobre las materias de gramática, lógica, filosofia natural o teologia. Esta faceta pedagógica del convento tenia además su exteriorización ya que la propia villa ponia los medios para que los agustinos pudiesen hacerse cargo de la formación de los niños alcoyanos en las escuelas municipales.

Este celo intelectual precisaba necesariamente de una surtida biblioteca como la que tenia el convento de Alcoy, instituida desde su fundación bajomedieval e incrementada tanto por la adquisición de libros como por las propias obras de los religiosos. Junto a ello los frailes elaboraban en el "scriptorium" libros de uso litúrgico que tenian abonada clientela entre las numerosas parroquias vecinas como es el caso del cabildo de la Colegiata de San Nicolás de Alicante que adquirió en 1732 un misal confeccionado por el Padre fray Miguel Monllor en este convento ${ }^{54}$. Aunque la libreria funcionaba con los fondos del mo-

52 Ibid, pp. 36-37.

53 Regla y constituciones..., p. 93.

54 Escritura del 18 de noviembre de 1732. Protocolo de 1731-1733 del notario Thomás Gisbert, ff. $134 \mathrm{v}-135$, AMA. 
nasterio, algunos religiosos cedieron a su muerte las rentas que disfrutaban para aumento de la dotación de la biblioteca. Así el Padre fray Damián Candela, maestro de gramática del convento y de la villa, disponia que a su fallecimiento la renta anua de cincuenta libras que poseia se destinase a medias a la sacristia y la libreria, instituyendo por tanto una obra pia regentada por cuatro religiosos, dos decanos no graduados y dos lectores, más un procurador.

El cuidado y administración de la biblioteca debia adecuarse a las indicaciones de las constituciones que prohibian la venta de libros so pena de excomunión, la idoneidad de los locales para su almacén y la inserción de registros librarios indicando la propiedad del convento, elaborándose un catálogo para el buen uso de los fondos, mientras que por otra se impedia el acceso de personas ajenas sin licencia del prior. Los frailes podian sacar volúmenes para su uso individual mientras que cada año deberia realizarse un inventario general en manos del depositario o del subprior ${ }^{55}$.

La metodologia didáctica que se seguia en las aulas era la del tradicional "modus assertorius" en el que las explicaciones se hacian sobre la lectura de los libros tanto de carácter sagrado como de clásicos u obras contemporáneas de contenido dogmático. De esta forma se leia el texto en voz alta haciendo interrupciones para su comprensión, para que los alumnos pudiesen plantear preguntas ("quaestiones") o incluso para que los propios maestros diesen diferentes respuestas a ellas ("dissertationes") ${ }^{56}$. Fruto de este método fue que casi todos los libros hoy aparecen rellenos de anotaciones en tinta roja que los estudiosos incluian para mayor comprensión del texto ${ }^{57}$.

En el manual para novicios que escribió el P. Rosell, prior del Convento de Aguas Vivas, se describia este método de enseñanza para las humanidades indicando que al estudiante:

"se le den principios sólidos, generales, imparciales, comúnmente admitidos de todos...No se ha de contentar el Maestro con que lo tome bien de memoria sino que ha de hacer experiencia, declarándoselo por distintos modos y no parando hasta asegurarse de su penetración. Radicado en las Instituciones puede señalar obras maestras y limpiar de ojarasca donde leyendo pueda extender sus ideas y ver la aplicación de los principios. El exercicio que se tenga en el Aula más ha de ser de juicio que de memoria...medite [el maestro] algunas qüestiones y propóngalas a los discípullos, inquiriendo el sentir de cada uno y si hallase dos que disienten haga que arguya el uno y responda el otro según las Leyes...Oygáles pacientemente dando lugar a que piensen y hablen con seguri-

55 (Regula et constitutiones) Quinta pars. De forma circa studia, studentes, graduatos ac praedicatores in Ordine Nostro servanda. Cap. XI. De Libraria \& custodia Libroru, pp. 440-452.

56 MOLINER, J. M.: Espiritualidad medieval. Los mendicantes, Burgos, 1974.

57 ALONSO TURIENZO, P. T. (O. S. A. ): "Catálogo de los incunables de la Real Biblioteca del Escorial y Biblioteca de la Comunidad de Padres Agustinos" en La Ciudad de Dios, vol. CLXXXVII, Escorial, 1974, pp. 646-668.

DEL ESTAL, J. M., art" cit., pp. 57-58.

MOTA CLIMENT, M. J.: "Un nuevo incunable en el Archivo Municipal de Alcoy" en Cuadernos de bibliofilia, $\mathrm{n}^{\circ} 9$, Valencia, 1982 , pp. 59-64. 
dad y quando lo juzgue necesario ayúdeles con alguna razón. Concluida la disputa haga él mismo el epílogo aprobando y confirmando lo que esté bien resuelto y si no fuere así manifiesteles el error...Puedeseles encargar también quando ya estén algo adelantados que escriban Disertaciones. Para el Maestro no hay duda que este modo de instruir es más trabajoso que el de hacer que tomen de memoria lo que está en el libro o en el quaderno y que se arguyan y respondan"58.

En general los religiosos titulados encargados de la docencia eran los que mayor importancia tenian entre la comunidad y la mayoria de ellos acababan siendo nombrados priores o consejeros de la hermandad, como el Padre Maestro fray Andrés Abat, prior entre 1720 y 1723, el Padre Presentado fray Antonino Sanchis, prior entre 1717 y 1720 y 1723 a 1729 , el Padre Maestro fray Gabriel Miralles entre 1738 y 1744 y el Padre Lector fray Vicente de Fanlo entre 1747 y 1750 .

\section{LA ACTIVIDAD ECONOMICA}

El Convento desde su fundación estaba dotado con una renta de doscientas libras anuas que pagaban los señores de la villa (dos tercios el Real Patrimonio y un tercio el Convento de Santa Clara de Xàtiva) de los ingresos fiscales, mientras que las escasas tierras que lo circundaban y que habian sido suyas las cedió al municipio a fines del XVI para la construcción del "raval nou".

La acumulación de capital que progresivamente se produjo dió lugar a su conversión en préstamo pues esta comunidad se caracterizó a lo largo de su historia por la renuncia a conservar bienes raices prefiriendo la renta por via de censal u otros instrumentos de crédito. Las escasas compras que el convento realizó en este periodo incluso venian motivadas por factores externos ya que la acumulación de deudas impagadas obligaba a los deudores a traspasarle la propiedad hipotecada aunque estas tierras y casas que revertian a la comunidad eran de nuevo vendidas mediante la constitución de un censo por el valor tasado. En muchos casos lo que se traspasaba eran edificios arruinados que ya no servian de hipoteca y por lo cual se habian comisado y se ofrecian como solares.

A pesar que la Regla estipulaba que los frailes no podian poseer bienes propios sino en comunidad, en realidad todos los tenian en usufructo por lo que iban acumulando capitales que al igual que hacia el convento los destinaban al préstamo. De esta forma, los cargamientos de censos, obligaciones o ventas a carta de gracia ofrecian dos modalidades: en una se reconocia la titularidad del monasterio en cuanto al capital y la renta, mientras que en la otra el capital se reconocia al convento y la renta al religioso que habia realizado el préstamo y que cobraria hasta su muerte pasando luego a la comunidad que por este medio continuaria acaparando capitales.

En la primera mitad del XVIII el sistema predilecto para la constitución de rentas era el censo puesto que aún se mantenia un interés del cinco por ciento y en algunos casos del

58 P. fr. Basilio Tomás ROSELL, op. cit., pp. 269-270.

(Regula et constitutiones. .), pp. 397-4210. 
$666 \%$. Aunque en el cargamiento el censatario lo imponia sobre su persona y bienes, en realidad fijaba unos determinados como "especial de censo" o hipoteca. En general se cargaba sobre bienes raices o sobre otros censos pero nunca sobre oficios u otro tipo de ingresos; en cuanto a su naturaleza, predominaba la propiedad agraria, tanto de grandes como de pequeñas fincas, frente a la urbana. Estos contratos de creación de censos solian incluir una serie de cláusulas que bien podian ser de tipo formulativo, acordadas entre partes o impuestas por el prestamista. En el primer caso se encontraban las condiciones más frecuentes pues se trataba de recordar al deudor el buen cuidado de la hipoteca, que siempre estuviese sujeta al censo y por ello (cosa bastante habitual) que no pudiese ser vendida como franca y que en el caso de ser alienada el nuevo propietario reconociese la carga y se obligase a responderla.

La redención del censo por su parte se fijaba por acuerdo entre censualista y censatario mientras que en ocasiones el prestamista fijaba unas condiciones que podian ser excepcionales o incluso muy duras. Por ejemplo hasta 1720 solia incluirse la cláusula "que mientras no se redima el censo ni se parta ni divida ni se imponga otro censo ni se traspase a ninguna persona de las prohibidas en derecho excepto los legos, de quien se pueda cobrar, sin que el censualista lo sepa diez dias antes so pena de comiso", lo cual daba un carácter más restrictivo que el simple censo consignativo ya que se atribuia el derecho de vetar nuevas cargas, evitando así que se acudiese a otros prestamistas, o enajenar la hipoteca sin su conocimiento. En algunos casos, al tratarse de bienes de escaso valor respecto al censo que se imponia, el censualista exigia que en un plazo determinado se aumentase la hipoteca, siguiendo el tradicional "pacte de millora" del censal de la época foral, o que se librasen las cargas que pesaban sobre ella.

El otro medio para acaparar censos era comprar su titularidad a otros censualistas. De los centros conventuales de Alcoy, el de San Agustín era el mayor comprador que, junto a los que adquirieron sus religiosos a título particular, lo situaban en más del $95 \%$ de los censos vendidos al clero regular. Todos ellos tenian la hipoteca en el término de la villa mientras que algunos censualistas eran foráneos y curiosamente los vendian a precios inferiores a su capital. De esta forma los rentistas alejados de la población, con peligro de ver perder las pensiones, preferian traspasarlos aún a menor valor mientras que los religiosos sólo aceptaban aquellos de base hipotecaria en la vecindad y que derivaria en la posibilidad de un mayor control sobre los censatarios.

Otras formas de préstamo al margen del censo, pues éste comportaba ineludiblemente unos intereses regulados por ley y unos bienes de hipoteca, permitian rentas más elevadas como las obligaciones y ventas a carta de gracia que aparecen en la documentación notarial o los contratos privados como vales o cambios. La venta a carta de gracia era una escritura de compraventa en la que el vendedor se reservaba el derecho de recuperar lo vendido mediante la devolución del valor pagado ${ }^{59}$ y que escondia un préstamo usurario con unos inte-

59 FERRER i ALOS, Ll.: "Ventas a carta de gracia y endeudamiento en la comarca de Bagés en el siglo XVIII" en Actas de las II Jornadas de Metodologia Histórica Aplicada, vol. II, Santiago de Compostela, 1984 , p. 410 
reses sin determinar por encima de lo permitido en los censos ${ }^{60}$. La aparición de este tipo de contratos fue bastante tardia, a partir de 1732, y siempre en contadas ocasiones, con unas características generales por tratarse de ventas de tierras por un plazo de ocho años. Otro medio para el crédito al margen del censal eran las obligaciones por las cuales el deudor reconocia haber tomado un valor en metálico o en especie y se comprometia a devolverlo en cierto plazo. En este caso los prestatarios siempre eran familiares de los frailes que tomaban un préstamo urgente y sin los formulismos que representaba la constitución de censos o la venta a carta de gracia.

Este sistema rentista basado principalnmente en los censos llevaba anejo el problema del impago de las pensiones, sobretodo en el caso de grandes censatarios como el municipio de Alcoy. Ante el fracaso reconocido de los acreedores para cobrar las rentas atrasadas debido a la lentitud de la justiticia y la resistencia de los deudores, los censualistas como el convento de San Agustín optaron por una via de diálogo por medio de convenios y concordias apartándose de pleitos, facilitando los pagos de las cantidades adeudadas y llegando incluso a la rebaja del tipo de interés ${ }^{61}$. Lo que se muestra claramente es que a partir de 1730 se desarrolló la mayor fase de control de los censatarios por el impago de las rentas censales relacionada con la grave crisis económica que azotó la zona tras las desastrosas adversidades climáticas que se cebaron sobre el campo durante el quinquenio de 1725 a 1730 . Este control tuvo dos manifestaciones según el carácter del deudor: en el caso de grandes débitos como presentaba el municipio alcoyano se optó por pactos y convenios para su arreglo, mientras que cuando se trataba de pequeños censatarios eran instados por los procuradores del monasterio a comparecer ante el escribano de la villa y reconocer tanto el censo como las pensiones que debian.

El Concejo de Alcoy respondia diversos censales a diferentes personas e instituciones, entre ellos el convento agustiniano, por un capital total de sesenta y seis mil libras ${ }^{62}$. En 1710 , a consecuencia de las multas impuestas por D'Asfeld y la introducción del equivalente, el municipio se halló sin fondos para pagar las pensiones vencidas, lo que motivó que prontamente uno de sus acreedores instase ejecución de bienes pero que no llegó a producirse. Volvió a plantearla en 1719 y el resto de los censualistas, viendo peligrar sus posibiliaddes de cobro, acordaron convenir con el síndico de la villa la paralización del embargo, la regulación de los pagos y la distribución del turno para cobrar. Lo que se negociaba no era una reducción de la deuda sino un aplazamiento con la esperanza que la villa quedase

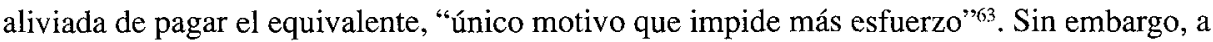
pesar de realizarse diversos repartimientos entre los vecinos y quedar los ingresos de propios y arbitrios en manos de los acreedores, se seguia sin cubrir la deuda y ésta aumentaba

60 Id.: "Censals, vendes a carta de gràcia i endeutament pagés al Bagés (segle XVIII)" en Estudis d' història agraria, $\mathrm{n}^{\mathrm{0}}$ 4, Barcelona, 1983, p. 115.

61 ANDRES ROBRES, F.: Crédito y propiedad de la tierra en el País Valenciano, Valencia, 1987, pp. 67-68.

62 PESET, M. ; GRACLLERA, V.: "Els censals i la propietat de Ia terra al segle XVIII valenciă" en Recerques, $\mathrm{n}^{\mathrm{O}}$ 18, Valencia, 1979, p. 123.

63 Escritura del 10 de noviembre de 1719. Protocolo de1718-1720 del notario Pedro Tarasona, ff. $118 \mathrm{v}-$ $128 \mathrm{v}, \mathrm{AMA}$. 
progresivamente. Ante esta situación se convocó en 1732 una nueva junta de censualistas en Valencia acordándose que se rebajaria el interés de un cinco a un 3'75\% y se permitiria que se dedicasen quinientas libras cada año al quitamiento de censos. Este cambio de actitud de los acreedores era revelador de un sistema que tocaba fondo: la rebaja que se permitia intentaba evitar la quiebra del censatario que supondria la pérdida irreversible de los censos, mientras se acercaba al tipo castellano de un 3'33\%. Esta tendencia se acrecentó cuando en la nueva concordia de 1746 los acreedores incrementaron el volumen dedicado a quitamientos y dieron facilidades de pagos al reducir los atrasos en un diez por ciento en el momento de la redención. Como vemos a través de sucesivos acuerdos la posición de los censualistas fue variando gradualmente siguiendo un ritmo que era igualmente adoptado en otros lugares en el que si en un principio se ignoraba la posibilidad de quitar censos, los continuos pleitos y los impagos habian calado en un grupo que ahora preferia recuperar el capital y destinarlo a otros menesteres. No es extraño pues que este proceso coincida con el que ha estudiado Andrés Robres sobre el Colegio del Corpus Christi de Valencia que a partir de 1750 se dedica a recuperar capitales de censos e invertirlos en tierras y casas $^{64}$. De todas maneras estas concordias no supusieron la solución de los conflictos entre la villa y sus acreedores ni tampoco la puesta al dia en los pagos; algunos censualistas hicieron llegar sus demandas para que se les pagasen sus pensiones ${ }^{65}$ mientras la Intendencia del Reino les conminaba a presentar sus proposiciones de quitamientos, entre ellos el de San Agustín en $1772^{66}$.

Si el censualista trataba de evitar la ruina del municipio igualmente lo hacia con los pequeños censatarios. A pesar que en los cargamientos se incluia una cláusula por la cual si en cuatro años consecutivos no se pagaban las pensiones se comisaria la hipoteca, en general se pactaba el arreglo de la deuda abonándose debidamente la pensión viva y la muerta hasta saldarla, asegurándose de este modo el cobro a medio o largo plazo ya que de hacerlo de inmediato arruinaria al censatario. En algunos casos sin embargo éste preferia perder la propiedad gravada traspasándola al acreedor y aboliendo la carga censal antes que enfrentarse a la costosa demanda judicial de embargo de bienes. De todos modos estas ejecuciones no abundaron pues el censualista sólo hacia uso de ellas cuando el deudor aparecia en rebeldia o declaraba no poder hacer frente a las pensiones. Los religiosos preferian pactar con sus censatarios antes que despojarlos de sus bienes.

La actuación de los acredores rebajando el tipo de interés supuso en realidad un avance a la medida del gobierno del 6 de julio de 1750 de reducirlo de un cinco a un tres por ciento para todos los Reinos. Este hecho ha sido relacionado en muchos casos, como el del Colegio del Corpus Christi, con el progresivo abandono de la inversión en censos y la pre-

64 ANDRES ROBRES, F., op. cit., p. 91.

65 Carta del Colegio mayor de Santo Tomás de Villanueva de Valencia del 3 de enero de 1767 para que la villa de Alcoy les pague las pensiones que les debe de dos censos que son dotación de una beca de estudiante pobre en dicho colegio, contenida en Expedientes y causas (1731-1770), s. f., AMA.

66 "Expediente sobre que los Acrehedores Censualistas corrientes sobre el común de vezinos de esta villa hagan de Orden del señor Intendente G(enera)l de este Reyno en precisso término de diez dias sus Proposiciones para Quitamientos", (1772) entre los que se halla el del Convento de San Agustín, en Censales (1721-1915), s. f., AMA. 
ferencia por las compras de bienes raices. El Convento agustiniano de Alcoy sin embargo, a pesar de esta medida de rebaja, no transformó su sistema basado en el crédito pero sí lo iba a encauzar hacia una tipologia no regulada y al margen de la legalidad en cuanto al interés que se fijaba. Aunque por el momento estamos en un nivel aproximativo podemos entrever que la segunda mitad de siglo supuso para este monasterio la desaparición del censo como forma de inversión, pero fiel a su tradición de rehuir de la posesión de propiedades, encaminó los capitales que dedicaba al préstamo por medio de las cartas de gracia en dos modalidades: reservándose el vendedor la propiedad a cambio de abonar la renta anual o entregándola al convento para su arrendamiento a terceros. De esta forma ni alteró su tradicional sistema crediticio ni se vió afectado por la rebaja del interés del censo.

Hasta ahora hemos hablado de ingresos procedentes de la conversión de capital en préstamo pero el convento mantenia otros por via de legados, pagos de servicios religiosos, instituciones o por cualquier otra razón. En todos estos casos se preferia pagar en metálico o mediante traspasos de censos antes que mediante cargamientos censales pues los otorgantes ante todo querian evitar mayores gravámenes sobre sus bienes. Así aunque suponia una salida de capital del cuerpo de la herencia se eludia en todo caso la creación de nuevas cargas.

\section{LA DEDICACION APOSTOLICA Y LA FORMACION DE CLIENTELAS}

Como otra de las órdenes mendicantes, la agustiniana debia ocuparse primordialmente de la actividad apostólica, predicando el verbo divino en todos los lugares que fuese posible. Ello le conducia de hecho al enfrentamiento con otras comunidades dedicadas a la prédica como dominicos o franciscanos. Con los primeros fueron célebres los conflictos que se produjeron en Valencia en la primera mitad de siglo mientras que en Alcoy la disputa se sancionó en favor de los recoletos de San Francisco que, tras la voladura de su casa en los sucesos de la guerra de Sucesión, contaron con la solidaridad del concejo municipal y del cabildo parroquial cuando se enfrentaron a los agustinos por el control de la prédica. En uno de los ejemplos más significativos como era la contratación para los sermones de cuaresma o de festividades locales como San Jorge o el Santo Sepulcro, los predicadores agustinos aparecen esporádicamente frente a la habitual concurrencia de los recoletos o en ocasiones de dominicos procedentes de otros lugares. De esta forma en todo el XVIII sólo en tres años se requirió un predicador agustino para la cuaresma y en otros tres para distintas celebraciones ${ }^{67}$. Los predicadores debian de estar de todos modos aprobados y con licencia del ordinario eclesiástico de la población para poder ejercer ${ }^{68}$.

67 Fray Antonino Sanchis, subprior del convento, predicó en 1709 el sermón del dia de San Jorge y el de "festividad que hizo esta villa [de Alcoy] en hazimiento de gracias de la rendición del castillo de Alicante". El prior fray Vicente de Fanlo predicó en 1749 y 1750 los sermones de cuaresma, San Jorge y del Santo Sepulcro. Fray Nicolás Verdú predicó en 1750 el sermón de San Jorge y fray Francisco Alonso en 1751 los de cuaresma, San Jorge y Santo Sepulcro, los mismos que hizo en 1757 el prior fray Thomas Bornay.

68 Regula et constitutiones...Quinta pars...Cap. IX. De Officio Praedicatorum, pp. 429-435. 
La especialización en la prédica no dejaba de lado que el resto de religiosos cuidasen la formación de unas clientelas tanto personales como colectivas hacia el convento. Así aparecian confesores y maestros espirituales de seglares mientras se potenciaba el papel de las hermandades como forma de captación de devotos de la Orden. Estas cofradias religiosas eran:

"corporaciones eclesiásticas formadas prevalentemente por seglares, erigidas canónicamente y gobernadas por el superior legítimo con el fin de promover la vida cristiana por medio del culto divino y de la caridad...verdaderas fundaciones eclesiásticas con capacidad jurídica para administrar sus bienes, recibir donaciones o herencias y desarrollar actividades"69.

El convento tenia dos hermandades de laicos asociadas, la de Nuestra Señora del Consuelo, a la que se habia unido la de San Nicolás, y la del Dulcísimo Nombre de Jesús ${ }^{70}$. Los miembros de la primera cofradia siempre indicaban en sus testamentos su pertenencia y casi siempre pedian ser enterrados en la sepultura propia de la corporación en la capilla de Nuestra Señora del Consuelo en la iglesia del convento, coincidiendo en general en proceder de sectores laborales como artesanos, "botiguers" o tratantes. Gobernada por un prior religioso del monasterio y por mayorales y oficiales laicos, la hermandad se dedicaba al cuidado de la capilla de su patrona, a la celebración de misas y oficios, a su iluminación y a auxiliar cofrades en peligro de enfermedad o de muerte, pagándose los gastos de las contribuciones de los hermanos o de legados por via testamentaria en agradecimiento de sus servicios ${ }^{71}$. Al tener sepultura propia de la de la hermandad sólo debian abonar la mitad del derecho de fuga a la Parroquia aunque a partir de 1748 el cura decidió cobrarlo íntegro lo que provocó las protestas de los cofrades y especialmente la intervención del convento en su defensa, pero sin resultado pues el vicario general falló en favor del párroco.

Junto a estas cofradias el monasterio también alojaba capillas de patronos y fosas comunitarias de algunos gremios de la villa como el de herreros o el de tejedores de paños. Los primeros tenian su oratorio en la capilla de San Aloy y en su sepultura sólo podian enterrarse los maestros gremiales, por el contrario el de tejedores tenia capilla pero no sepultura de uso común. La existencia de estas agrupaciones profesionales asociadas al convento garantizaba una permanente entrada de capital por via de limosnas y legados, y por otra parte permitia a los agustinos asegurarse una clientela frente al agresivo proselitismo franciscano $o$ al sistemático ataque que recibian del cabildo parroquial ante cualquier protesta.

69 ARIES, Ph., ed.: Historia de la vida privada, vol. III, Madrid, 1989, pp. 89-90.

CARCEL ORTI, V., op. cit., p. 141.

PEÑAFIEL RAMON, A.: Mentalidad y religiosidad popular murciana en la primera mitad del siglo XVIII, Murcia, 1988, p. 54.

70 CARBONELL, V., op. cit., p. 157.

P. fr. Jayme JORDAN, op. cit., vol. II, p. 114.

71 Este es el caso de la viuda de Gerardo Nicolau, de la clase de ciudadanos, que traspasó a dicha cofradia 155 libras que le debia el molinero Joseph Carbonell por las asistencia que de ella habia recibido en su enfermedad. Escritura del 15 de julio de 1749. Protocolo de 1746-1751 del notario Cosme Sampere, ff. 406 r-v, AMA. 
Frente a la masiva presencia de miembros de la tercera orden franciscana, en el caso de los agustinos se reducia a escasos ejemplos, tan sólo tres mujeres que aparecen como "beatas" y que conocemos gracias a sus testamentos. De ellas sólo una habia hecho profesión de votos (a la edad de 49 años) pero todas disponian que a su muerte se celebraran funerales de extrema sencillez, se las enterrase con el hábito que vestian y en ocasiones con el de franciscano debajo. Eran hijas de medianos propietarios agrícolas que no habian accedido al matrimonio y quizá perdida esta esperanza se habian consagrado a una religiosidad personal dirigida por los maestros espirituales.

Conocer la existencia de confesores en esta época resulta harto díficil pues se reducia a la única presencia en los testamentos de aquel individuo a quien se le cedia el cumplimiento de órdenes misteriosas. Casi nunca se indicaba que lo fuera pero se puede conocer en aquel al que se le legaba un dinero para cumplir "lo confiado en secreto natural", "el que li tinch encomanat en secret", o como dice Vovelle, misiones "confiées a l'oreille" "72. El poder de estos confesores se acrecentaba cuando se hallaban ante moribundos y podian beneficiarse de ello por lo que desde el Gobierno "se declaró [en 1713] que no valiesen las mandas que se hiciesen en la última enfermedad al confesor ni a sus deudos, iglesias y religiones para evitar todo fraude" pero sin efecto hasta 1783, mientras que la curia romana dispuso que cualquier confesor tenia que estar aprobado por el ordinario del lugar de los penitentes $^{73}$. De las numerosas ocasiones en que se vislumbran presuntos confesores tan sólo en dos el testador indica que lo sean, una en el caso de fray Miguel Martí, confesor del corregidor Luis de Costa y Quiroga, y otra como "padre espiritual" de Manuela Almunia, de la familia de los señores de la Sarga, Sanet y Negrals, y aparecian más vinculados a las féminas que a los hombres e incluso de ellas recibian mayores legados. Aunque gran parte de las mandas debian dedicarse al cumplimiento de últimas voluntades era frecuente que se recompensasen sus servicios espirituales.

Como se ha observado los agustinos utilizaban todos los medios posibles para mantener una clientela de seglares vinculada a él por lazos más o menos sólidos, sin dejar de lado el carácter familiar al ser muchos los devotos parientes de los religiosos, y que le servia para contrarrestar la presión franciscana tanto como la del clero parroquial. Mientras que los recoletos intentaban minarle una base populista, el segundo iba acabando progresivamente con los primitivos privilegios con que fue dotado y que ahora aparecian incompatibles con la hegemonia del secular sobre la cura de almas.

\section{¿UNA VIDA REGULADA?}

La vigencia de reglas de origen medieval para comunidades de religiosos significó que con el tiempo cada núcleo fue acomodándolas y practicando una cierta relajación. A partir

72 VOVELLE, M.: Pieté baroque et dechristianisation en Provence au XVIIIème siècle, Paris, 1978, p. 215.

73 Continuación a la historia eclesiástica general o siglos del christianismo del Abbate Ducreux que comprehende desde el año de 1700 en que la concluyó el autor hasta el actual pontificado de N. S. P. Pio VII, por los traductores de dicha obra, Madrid, 1805, pp. 309 y 401. 
de la segunda mitad del XVIII este hecho coincidió con la formulación de un programa de reformas del clero regular en un momento en que éste, humana e institucionalmente, habia decaido fruto de la proliferación incontrolada de religiosos y conventos. Como muestra, el sintético informe del Arzobispo Fabián y Fuero a Roma sobre el estado de la diócesis valentina en 1778 ofrece una patética visión sobre los graves incumplimientos de las constituciones en las casas de regulares. Uno por uno, cada instituto religioso es desvelado por el informante sobre las faltas que cometian:

de los dominicos, a pesar que son "los que menos se ven por las calles" dice que "no guardan vida común perfecta porque sobre percibir las limosnas de los sermones los mismos que los predican se ha introducido en algunos años a esta parte un cierto modo de adquirir peculios". De los mercedarios "en ninguno [de sus conventos] se guarda vida común perfecta pues les permiten el que puedan tener dinero para vestirse y para otras cosas con que dicen no les acude la religión". A los trinitarios "por ser escasas sus rentas les permiten igual licencia que a los de la Merced para retener las limosnas de algunos sermones y misas y percibir el usufructo de las cortas dotaciones que también tienen por sus casas", además "no guardan mucho retiro estos religiosos pues salen con frecuencia a la calle con nota de los seculares". Los mínimos "no guardan vida común perfecta aunque tienen la forma de comunidad" mientras tienen "mucha libertad para salir a la calle". Los cistercienses tampoco "guardan vida común perfecta" porque acabados los oficios "pasan ociosamente el tiempo" e incluso los del convento de la Valldigna "no predican ni confiesan ni tienen coro ni misa sino en los dias de fiesta. Pasan todo el tiempo en dicha ciudad [de San Felipe] andando por las calles, metiéndose en las casas particulares y haciendo otras cosas distantes de su instituto con poca edificación de los vecinos". Ni siquiera los agustinos "guardan vida común perfecta pues perciben las limosnas de los sermones que predican y de algunas misas y los maestros tienen distinción en el refectorio"74.

La relación de males que afectaban al regular podia resumirse en dos puntos: el fin de la comunidad de bienes y el desorden que conducia a salir a las calles. El tema económico entraba en relación con la crisis que afectó a todos los conventos valencianos: desde 1744 se pagaba tributación por los bienes adquiridos mientras la masiva afluencia de nuevos religiosos duplicaria el número habitual de residentes con lo que la dotación conventual, sin aumentar, entraba en desfase. La ruina del convento como centro económico provocó que cada fraile tendiese a asegurarse un patrimonio personal mediante el cobro de sus servicios religiosos o de la reserva de los bienes del siglo para su sustento. En cuanto a los que deambulaban fuera de las casas, desde un primer momento el Estado se apoyó en las resoluciones tridentinas para ratificar el control en los conventos por el que:

74 CARCEL ORTI, M" Milagros: Relaciones sobre el estado de las diócesis valencianas. II. Valencia, Valencia, 1989, pp. 114-121. 
"los Regulares no podrán salir de sus Monasterios y Conventos sin la Obediencia y Licencia in scriptis de sus Superiores, los quales expresarán en ellas las causas y tiempo de su concesión"75.

En la relación del arzobispo se conectaba ya este fenómeno con el de la desobediencia a los priores pues se aducia que:

"de la facilidad con que algunos han logrado breves de secularización ha nacido la falta de subordinación a los prelados en los claustros pues a poco que ahora estrechan a otros a la observancia de sus leyes les amenazan con que se secularizarán, de que se intimidan los superiores sin poder hacerse obedecer" 76 .

De todas formas no debemos pensar en un incumplimiento consciente del ordenamiento regular sino que las dificultades de la propia vida comunitaria invitaban a arrinconar en ciertos casos los preceptos de orden y a que preponderasen los más beneficiosos para la pervivencia del monasterio. De este modo un convento como el de Alcoy que ofrecia una extremada dificultad para mantener a sus religiosos llegó a desentenderse de cláusulas reglamentarias que empeorasen aún más su delicado estado económico y por ello es explicable la constante preocupación de los frailes para asegurarse una renta personal tanto antes como después de su profesión, capaz de subvencionar sus gastos, y en ocasiones de conservar sus bienes aún al margen del mandato de la Regla de ponerlos al servicio de la comunidad. Aunque en general los religiosos gozaban del usufructo de los bienes, algunos optaron por entregar las tierras en arrendamiento o cederlas a familiares a cambio de rentas mientras otros se decantaban por la explotación artesanal, como fray Christoval Terol, un profeso de servicio del convento, que mantuvo el negocio paterno de tintes financiado por otro religioso.

Pero no sólo el ejercicio de oficios y actividades mundanas contravenia ya los mandatos de la Regla sino incluso al propio voto de pobreza se le buscaba el aprovechamiento cuando en las escrituras de profesión o testamentos de novicios se habia omitido, por causas desconocidas, la renuncia del nuevo fraile a los bienes de herencia paternos, lo cual movia a que el convento en el momento del óbito de uno de los ascendientes entraba en pleitos con el resto de herederos. Algunos progenitores sin embargo solian prevenir estos sucesos entregando alguna compensación a sus hijos profesos para apartarlos de sus derechos de herencia y evitar el peligro de que en algún momento pasasen a manos del convento. Este, por otra parte, tenia medios para incrementar su patrimonio a través de los bienes que tocaban a los religiosos: por un lado en los préstamos que realizaban se imponia que su propiedad siempre quedase a nombre de la comunidad, de este modo a la muerte del fraile el monasterio incorporaba su renta, mientras que por otra se permitia:

"a los Religiosos profesos el que durante su vida puedan percibir y cobrar el usufructo de la propiedad que les tocase y perteneciere de la herencia de sus

75 R. Cédula de S. M. y Señores del Consejo por la qual se mandan cumplir las Reales Cédulas expedidas para que los Religiosos no vivan fuera de Clausura y que asi éstos como sus Superiores observen las Reglas que se prescriben quando tengan necesidad de pernoctar, Madrid, 22 de octubre de 1772.

76 CARCEL ORTI, M" Milagros, op. cit., p. 1144. 
Padres y después de su fallecimiento se hagan tres partes de dicha propiedad y la una de ellas sea, venga y pertenezca a dicha Religión y las otras dos debuelvan a sus herederos"77,

logrando de este modo la incorporación de nuevos bienes al convento. Estas medidas causaban gran recelo entre los familiares de los religiosos que en general se abstenian de nombrarlos herederos suyos para evitar que parte de su herencia pasase al monasterio o indicando expresamente en su última voluntad que el convento se apartase de los derechos al tercio de bienes.

Todo ello conducia a que el monasterio incorporase nuevas propiedades de realengo y las amortizase al igual que hacian otras instituciones eclesiásticas. El gobierno borbónico recelaba de esta progresiva pérdida del patrimonio franco e intentó aplicar una serie de medidas de contención, primero por el concordato de 1737 cuando se estipuló en el capítulo VIII que los bienes que incorporasen los eclesiásticos de realengo quedasen sujetos a tributación mientras que en 1749 se suspendió momentáneamente el derecho de amortización ${ }^{78}$. A partir del uno de enero de 1744 todos los bienes que pasasen al estamento eclesiástico debian pagar el equivalente ${ }^{79}$ aunque en el caso de Alcoy ya desde 1742 se llevaba una encuesta sobre las propiedades y censos que pasaban a manos de los conventos o de los clérigos ${ }^{80}$ e incluso en 1749 se formó una comisión presidida por el corregidor para averiguar las tierras del Real Patrimonio que habian sido ocupadas por los vecinos y que acabó acusando de ello al propio convento de San Agustín por una porción de tierra de la heredad del "Maset Roig"81.

A pesar de su carácter popular, las órdenes mendicantes como la agustina empeoraron la situación del bajo pueblo al tener que sustentarse con sus limosnas y consolidar además un sistema crediticio que se recondujo hacia estas clases con una mentalidad que se alejaba claramente de los preceptos de la Regla. La conversión de legados, donaciones o pagos de servicios religiosos en capital de préstamo no producia trauma alguno en los frailes de esta época e incluso cuando la via legal para la percepción de rentas empezó a ser desfavorable optaron por la creación de un nuevo sistema basado en un interés no declarado por medio

77 Testamento de Joachim Albors. 30 de enero de 1738. Protocolo de 1737-1738 del notario Pedro Barber, ff. 20-22v, AMA.

78 Continuación a la historia eclesiástica..., pp. 344-345.

MENENDEZ PELAYO, M.: Historia de los heterodoxos españoles, vol. VI, Santander, 1947, p. 67

MILLAN, J.: Rentistas y campesinos. Desarrollo agrario y tradicionalismo político en el sur del País Valenciano (1680-1840), Alicante, 1984, p. 284.

79 RUIZ TORRES, P.: "El País Valenciano en el siglo XVIII: la transformación de una sociedad agraria en la ẹ́poca del Absolutismo" en FERNANDEZ, R., ed.: España en el siglo XVIII, Madrid, 1985, p. 223.

80 En el Archivo Municipal de Alcoy (AMA) se encuentran tres informes de escribanos sobre las escrituras protocolizadas por el clero desde 1742 contenidas en el legajo Expedientes y causas (1731-1770), donde se detallan las tierras, censos y casas y cualquier otro tipo de escrituras de transmisión de propiedad que habian sido realizadas a favor del estamento eclesiástico en Alcoy. Otros informes se encuentran en el legajo de Equivalente (1751-1800).

81 Reclamación de fray Agustín Tudela, procurador del Convento de San Agustín, sobre una tierra propia parte del "Maset Roig" que se ha declarado de realengo (1754), contenida en Culto, s. f., AMA. 
de intrumentos como la venta a carta de gracia. Esa postura contra las clases populares se manifestó asimismo en el control que como rentistas ejercian por medio de los reconocimientos de censos que se cebaron especialmente sobre labradores y artesanos mientras que los estamentos privilegiados, característicos clientes del crédito del convento, parecian estar al margen de estas requisitorias.

La vida regular dentro del monasterio era otro de los aspectos en que más se reconocia el relajamiento de esta época y que mayor preocupación suscitaba en la jerarquia eclesiástica. Aunque en origen algunos religiosos estaban autorizados a faltar a algunos ejercicios o a marchar fuera del convento por su dedicación a la prédica o a los negocios de la comunidad, con el tiempo se multiplicaron pues tomaron costumbre de llevar acompañantes mientras que gran número aducia situaciones familiares o personales para poder salir del monasterio e incluso algún religioso preferia alojarse en casa particular antes que en la de la Orden. Por otra parte se apreció asimismo un relajamiento de la clausura al ser admitidos cada vez con mayor frecuencia seglares en las salas conventuales, de esta forma la celda prioral sirvió en numerosas ocasiones de lugar de reunión del gobierno municipal cuando la casa de cortes estaba en obras mientras se estableció a fines del XVII una antigua aula de estudios como sede del gremio de tejedores. Algunos particulares accedian incluso al claustro que por su extensión y tranquilidad parecia óptimo para realizar negocios de cualquier tipo ante el escribano requerido. Y no sólo la pretendida paz conventual era sacudida en el interior sino que incluso al exterior debia soportar que a sus muros se adosasen los puestos de ventas que implicaban que el convento quedase inmerso dentro de la algarabia típica de los dias de mercado.

Pero de todas, la lacra más criticada en los ambientes ilustrados era la falta de preparación de los religiosos tanto al servicio del culto como en la prédica y que fue satirizada por el Padre Isla en la figura del "famoso predicador fray Gerundio de Campazas", que aparecia como un cúmulo de los defectos de los regulares, especialmente de aquellos dedicados a la predicación a quienes se recriminaba su escasa o nula instrucción ${ }^{82}$.

Otro problema que se planteaba era el del excesivo número de religiosos que albergaba el convento y que a mediados del XVIII alcanzó su máximo volumen. El peligro era múltiple porque para su mantenimiento se recargaba el peso sobre los grupos laborales susceptibles de abonar las limosnas mientras que por otra era vital la existencia de una renta vitalicia para cada religioso sostenida por sus familiares. Ello contribuia a que los frailes tuviesen una excesiva dedicación a la conservación de su patrimonio mientras la comunidad buscaba mantener su sistema financiero aún a costa de la reducción del interés censal y por ello acudiendo a otros sistemas de mayor extracción de renta como los préstamos no formalizados por escritura o las ventas ficticias que los enmascaraban. La solución según los ilustrados residia en limitar el acceso de nuevos novicios pero esta medida, que podia suponer un golpe de gracia para muchos institutos, no entró en aplicación hasta el periodo doceañista cuando, entre las medidas secularizadoras, se incluyó el fin del ingreso de nuevos probantes y la exclaustración de los existentes.

82 P. ISLA: Historia del famoso predicador fray Gerundio de Campazas, 2 vols., Madrid, 1978 GARCIA VILLOSLADA, dir.: Historia de la Iglesia en España, vol. IV, Madrid, 1979, p. 634. 
Esta masificación de profesos no implicó sin embargo un auge de las clientelas laicas vinculadas a la comunidad religiosa sino que por el contrario entraron en decadencia hasta Ilegar las gremiales a ser abolidas a fines de siglo. Unido a ello a mediados del periodo estudiado desaparecian las últimas beatas lo que puede ser un síntoma del fin de la espiritualidad barroca en lo que atañe a los devotos. Paralelo a ello es significativa la progresiva desaparición de las instituciones que requerian gran número de oficiantes y llegaban a afectar al propio desarrollo de los ejercicios conventuales.

Esta época acarreó por otra parte un gran enfrentamiento del monasterio con las otras comunidades religiosas de la villa, la franciscana y la parroquial. A la primera intentó impedir su nuevo establecimiento en 1717 aduciendo que estaba muy cerca de su solar y que algunas bulas papales impedian su edificación a tan escasa distancia. En todo caso los agustinos trataban de beneficiarse de la ausencia de los franciscanos pues éstos, sin lugar donde alojarse de forma regular, se dispersaron por otros conventos, evitando así su reinstalación. En el caso del clero parroquial los frailes ofrecian una postura defensiva frente a las constantes presiones para ir eliminando privilegios de origen medieval y que la nueva política regalista preferia que estuviesen en manos del secular antes que en las órdenes religiosas. Por este motivo el convento tuvo que claudicar a sus prerrogativas de hermandades favorecidas con exenciones frente a la Parroquia o de mantener la exclusividad de oficiar en su templo.

En conclusión, la Regla representaba el espíritu de la Orden mientras las constituciones atendian las necesidades y buen gobierno de la vida comunitaria, pero todo ello estaba en función de la propia dinámica del núcleo religioso, pues su ubicación, su fondo patrimonial o incluso la formación de sus hermanos suponia una mayor o menor vigencia de los preceptos regulares. 